\title{
MMP13 Gene
}

National Cancer Institute

\section{Source}

National Cancer Institute. MMP13 Gene. NCI Thesaurus. Code C102921.

This gene plays a role in proteolysis of collagen. 